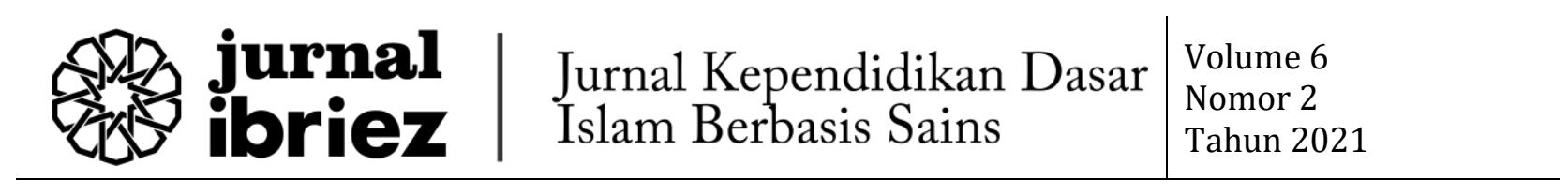

\title{
IMPLEMENTASI MANAJEMEN EMOSI PADA ORANG TUA DENGAN ANAK BERKEBUTUHAN KHUSUS
}

\author{
Yulia Anggraini \\ Institut Agama Islam Negeri Ponorogo \\ Surel: anggraini@iainponorogo.ac.id
}

\begin{abstract}
Abstrak
Penelitian ini bertujuan untuk memperoleh gambaran yang lebih mendalam dalam manajemen emosi orang tua yang memiliki anak berkebutuhan khusus. Subjek penelitiannya adalah orang tua dengan anak berkebutuhan khusus di SD Immersion, SD Inklusi di Ponorogo. Terdapat lima indikator dalam manajemen emosi yaitu self awareness (kesadaran diri), managing emotion (pengaturan emosi), motivating oneself (motivasi untuk diri sendiri), emphaty (empati) dan social skill (keterampilan emosi). Ada dua sikap yang bertentangan dalam memanajemen emosi orang tua, yaitu ada orang tua yang menyadari dan melihatnya sebagai takdir, dan ada juga orang tua yang tidak menerima kenyataan. Dengan dua sikap yang berlawanan ini, orang tua dapat mengoptimalkan kemampuan anakanaknya jika mampu menerima kekurangan anaknya. Sementara orang tua yang tidak dapat menerima situasi anaknya dapat membuat orang tua memiliki perasaan rendah diri, merasa hancur dan depresi atas situasi yang dialami anaknya. Pendekatan dalam penelitian ini yaitu pendekatan kualitatif dengan menggunakan field research, dengan teknik pengumpulan data menggunakan interview. Dari hasil analisis, didapatkan bahwa orang tua yang dalam penelitian ini adalah ibu, menggunakan kesadaran diri, keterampilan emosi, motivasi diri sendiri dan empati dalam memanajemen emosi mereka dan dalam pengaturan emosi kurang maksimal dilakukan sehingga masih belum dapat menahan emosi saat mengasuh dan mendidik anak berkebutuhan khusus mereka.
\end{abstract}

Kata Kunci: anak berkebutuhan khusus, manajemen, emosi, manajemen emosi, orang tua

\footnotetext{
Abstract

This study aims to obtain a more in-depth picture in the emotional management of parents who have children with special needs. The research subjects were parents of children with special needs at Immersion Elementary School, Inclusive Elementary School in Ponorogo. Goleman said that there are five indicators in emotional management, namely self-awareness, managing emotion, motivating oneself, empathy and social skills. There are two opposing attitudes in managing parents' emotions, namely there are parents who realize and see it as destiny, and also parents who do not accept reality. With these two opposing attitudes, parents can optimize their children's abilities if they are able to accept their children's shortcomings. Meanwhile, parents who cannot accept their child's situation can make parents feel low self-esteem, feel devastated and depressed. The approach in this study is a qualitative approach using field research, with data collection techniques using interviews. From the results of the analysis, it was found that the parents in this study were mothers, using self-awareness, emotional skills, self-motivation and empathy in managing their emotions and in managing emotions
} 
less than optimally so that they were still unable to contain emotions when caring for and educating their children with special needs.

Keywords : parents, children with special needs, emotional management

\section{A. PENDAHULUAN}

Lembaga terkecil dalam kehidupan kita adalah keluarga, yang memiliki komposisi ayah, ibu dan anak yang ketiga komposisi ini saling membutuhkan, berkaitan, dan saling ketergantungan satu sama lain. Keluarga adalah tempat kita pulang sehingga memiliki peran dan fungsi masing-masing, terutama orang tua yang mempunyai tanggung jawab penuh terhadap kehidupan anaknya terutama dalam menghidupi serta mendidiknya.

Effendi menyatakan bahwa ada fungsi yang wajib untuk dilaksanakan oleh keluarga yaitu, pertama adalah fungsi biologis yaitu orang tua yang bertujuan untuk melanjutkan keturunan, mengasuh serta mendidik anak. Fungsi kedua adalah fungsi psikologis, yaitu anggota keluarga yang saling suport antara satu dengan yang lain. Fungsi ketiga adalah fungsi ekonomi, yaitu peran dan tanggung jawab orang tua adalah untuk mencari dan mengelola pendapatan yang didapat, dan yang fungsi keempat adalah fungsi pendidikan, yaitu peran orang tua adalah menyekolahkan anak, mendidik anak melalui adaptasi, membina setiap tumbuh kembang serta mensuport bakat serta minat anak untuk mempersiapkan kehidupannya di masa yang akan datang. ${ }^{1}$

Siapa pun yang memiliki keluarga sangat mendambakan anak atau bayi yang sehat. Memiliki anak yang sehat jasmani dan mampu berkembang baik fisik maupun mental adalah keinginan terbesar orang tua, tetapi cita-cita dan kenyataan terkadang berbeda, karena anak mengalami pertumbuhan dan perkembangan yang tidak normal selama kehamilan atau setelah lahir atau biasa disebut memiliki kebutuhan khusus.

Anak berkebutuhan khusus merupakan anak yang mempunyai kelainan raga, hambatan pertumbuhan, kesusahan belajar, serta membutuhkan pembelajaran ataupun pelayanan spesial. Bagi Desiningrum, prevalensi anak berkebutuhan spesial bertambah di Indonesia serta PBB memperkirakan ada 10\% anak umur sekolah berkebutuhan khusus. Tetapi, informasi terkini serta tercatat di Indonesia, prevalensi anak berkebutuhan khusus, dikumpulkan dari 1. 544. 184 anak, dengan rentang umur 518 sampai 330. 764, ataupun dekat 21, 42\%. Dari prevalensi tersebut, cuma 85. 737 anak berkebutuhan pembelajaran spesial yang bersekolah di sekolah spesial ataupun disebut dengan inklusi. ${ }^{2}$

Menurut Aydin \& Yamac, ketidakhadiran anak normal dapat mempengaruhi penerimaan atau penolakan orang tua dengan anak berkebutuhan khusus sesuai usia. Penelitian Onder dan Gulay juga menunjukkan bahwa, orang tua dari anak berkebutuhan

\footnotetext{
${ }^{1}$ Kisworowati, “Strategi Coping Ibu dalam Menjalani Peran sebagai Orang Tua Tunggal” (Surakarta, 2010).

2 Dinie Ratri Desiningrum, Psikologi Anak Berkebutuhan Khusus (Yogyakarta: Psikosain, 2016).
} 
khusus memiliki tingkat penolakan yang lebih tinggi daripada orang tua dari anak yang berkembang normal. ${ }^{3}$

Novita mengatakan ada dua sikap yang bertolak belakang, yakni ada orang tua yang mengakui dan melihatnya sebagai takdir, dan ada juga orang tua yang tidak menerima kenyataan. Dengan dua sikap yang berlawanan ini, orang tua dapat mengoptimalkan kemampuan anaknya jika dapat menerima kekurangan anak berkebutuhan khusus. Sedangkan orang tua yang tidak dapat menerima keadaan anaknya dapat membuat orang tua menjadi rendah diri, merasa tertekan dan tertekan dengan keadaan anaknya ${ }^{4}$

Orang tua mengalami stres berat ketika memiliki anak berkebutuhan khusus dan hal tersebut dapat mempengaruhi kesehatan mental mereka. Pernyataan ini didukung oleh pendapat Lestari bahwa salah satu sumber stres adalah adanya anggota keluarga yang berkebutuhan khusus. Stres orang tua dapat memancing respons emosional dalam dirinya, yang disebabkan oleh penolakan dari keluarga dan orang-orang di sekitarnya. Ketika anak berkebutuhan khusus didiagnosis, peran utama dimainkan oleh orang tua, yang memiliki andil terbesar dalam merawat anak mereka yang memiliki kondisi medis berbeda dari anak normal. ${ }^{5}$

Menurut Puspita, ketika orang tua mengetahui bahwa anak mereka didiagnosa berkebutuhan khusus, reaksi pertama adalah shock, malu, sedih, berusaha menghindar, kurang mempercayai, dan merasa bersalah. Hal yang sulit bagi orang tua untuk melalui tahapan tersebut hingga akhirnya mampu untuk pada kondisi dan tahap menerima ${ }^{6}$

Ayah, sebagai laki-laki, pada umumnya memiliki kepribadian yang berbeda dengan perempuan. Proses sosialisasi anak akan memainkan peran yang penting dalam hal ini. Sehingga hal itu disebut "peran seksual" yang membedakan peran laki-laki dan perempuan. Ayah yang dalam budaya patriarki era Freudian digambarkan sebagai sosok yang kuat dan menakutkan bagi anak, sehingga anak menggunakan nilai-nilai ayah untuk menghindari hukuman dari ayah. Dalam kebudayaan Jawa, dijelaskan oleh Koentjaraningrat bahwa hubungan antara anak dan orang tuanya, terutama orang tua, ditandai dengan kepatuhan atau menurut dan nunduk. Dianggap kurang sopan dan kurang pantas bagi orang tua untuk berbicara dan dibantah oleh anak-anak mereka. ${ }^{7}$ Faktor anak adalah faktor yang tidak bisa diabaikan dalam perilaku orang tua ayah. Marsagliio menyatakan bahwa orang tua (ayah) pada umumnya lebih nyaman dengan anak laki-laki dibandingkan dengan anak perempuan.

\footnotetext{
${ }^{3}$ Aydin Aydan \& Yamac Ali, "The Relations between the Acceptance and Childrearing Attitudes of Parents of Children with Mental Disabilitie," Eurasian Journal of Educational Research, No. 54 (2014).

${ }^{4}$ Eryanti Novita, "Perbedaan Penerimaan Diri Ibu Yang Memiliki Anak Tunagrahita Ditinjau dari Tingkat Pendidikan di SLB-E PTP Medan,” Jurnal Diversita 3, No. 1 (2017): 55, https://doi.org/10.31289/diversita.v3i1.1180.

5 Jurnal Empati, Sarah Nur Rachmawati, and Achmad Mujab Masykur, "Pengalaman Ibu Yang Memiliki Anak Down Syndrome," Empati: Jurnal Karya Ilmiah S1 Undip 5, No. 4 (2016): 822-30.

${ }^{6}$ S. Rachmayanti and A. Zulkaida, "Penerimaan Diri Orangtua Terhadap Anak Autisme dan Peranannya dalam Terapi Autisme," Jurnal Ilmiah Psikologi Gunadarma 1, no. 1 (2007): 97258.

${ }^{7}$ Koentjaraningrat, Kebudayaan, Mentalitas dan Pembangunan (Yogyakarta: Pustaka Pelajar, 1985).
} 
Marsaglio menduga bahwa sang anak mengidentifikasi diri dengan ayahnya, dan komunikasi ayah dan anak lelakinya menjadi lebih mudah. ${ }^{8}$

Seperti yang diperkirakan dari perspektif pembalikan peran, pada abad ke-21 pria mulai memainkan peran yang lebih besar dalam perawatan dan pekerjaan rumah tangga. Gottman dan DeClaire menekankan pentingnya peran serta ayah dalam pengasuhan anak, khususnya dalam hal perkembangan kecerdasan emosional anak. ${ }^{9}$ Namun, kecenderungan ayah untuk berpartisipasi juga sangat tergantung pada usia ayah itu sendiri. Carnoy dan juga melaporkan dalam bukunya "Parents of a Certain Age" bahwa mereka mengamati bahwa orang tua yang lebih tua cenderung mengkhawatirkan anak-anak, dibandingkan dengan orang tua yang lebih muda yang lebih fokus pada masalah identitas. ${ }^{10}$ Dengan jelas bahwa keterlibatan orang tua tampaknya sangat penting saat ini dan memainkan peran yang lebih besar dalam pengasuhan.

Ibu adalah wanita yang umumnya diyakini memiliki kapasitas afektif yang kuat. Menurut Miller, Caughlin, dan Houston, wanita memiliki sifat feminin seperti kebaikan dan pengertian. Di mana-mana, budaya selalu melihat baik buruknya seorang anak, tergantung bagaimana sang ibu mengasuh anaknya. Banyak penelitian menunjukkan peran ibu dalam emosi anak yang membentuk temperamen anak. ${ }^{11}$

Sosok kunci yang merangsang dan mempengaruhi perkembangan anak adalah ibu. Pengaruh peran ibu telah berkembang sejak dalam kandungan sejak anak dilahirkan. Hal ini karena kesamaan genetik antara ibu dan anak membawa kecenderungan yang dialami anak. Ibu yang stres saat hamil memiliki anak yang rentan stres dan mudah mengekspresikan emosi negatif akibat stres psikologis yang dialami ibu selama kehamilan, sifat negatif dan emosi anak seusianya.

Studi tentang keterlibatan dan kepekaan ibu dalam pengasuhan menurut Brody, Stoneman, dan Nurke, serta studi oleh Getrarson dan Gelfand, menunjukkan bahwa seorang ibu sangat dibentuk oleh kebahagiaan perkawinan dan hubungan yang harmonis dengan pasangannya. Ketika dua hal ini tidak menguntungkan, ibu lebih mungkin mengalami depresi dan stres, dan sifat kebapakan mereka juga menjadi kurang positif. Namun, pola asuh ibu tidak dipengaruhi secara signifikan oleh faktor anak. Hal ini dapat terjadi karena ibu menyadari bahwa peran orang tua adalah tanggung jawabnya dan oleh karena itu pengasuhan tetap terjamin terlepas dari karakteristik anak. ${ }^{12}$

Emosi memainkan peran besar dalam kehidupan setiap orang, tetapi banyak orang masih tidak dapat memahami arti dari emosi mereka sendiri. Emosi adalah bagian integral dari sifat manusia. Kita semua memiliki emosi yang ada di dalam diri mereka, ketika emosi menghilang dari dalam diri individu maka mereka kehilangan aspek fundamental dari

\footnotetext{
${ }^{8}$ Andayani Koentjoro, Psikologi Keluarga: Peran Ayah Menuju Coparenting (Surabaya: Citra Medika, 2004).

${ }^{9}$ Koentjoro.

10 Koentjoro.

11 Koentjoro.

12 Koentjoro.
} 
kehidupan mereka sebagai pribadi. Emosi menentukan kualitas hidup seseorang, karena emosi selalu berperan dalam setiap hubungan yang dilakukan seseorang. ${ }^{13}$

Kemarahan adalah emosi negatif yang kuat yang dialami seseorang secara subjektif sebagai suatu keadaan yang disebabkan oleh antagonisme terhadap seseorang atau dipandang sebagai sumber dari suatu kejadian yang tidak menyenangkan. Gagasan antagonisme semacam itu menyiratkan ketegangan, konflik, perlawanan, atau serangan yang terus-menerus terhadap sumber ancaman yang dirasakan.

Marah adalah emosi yang wajar dan alami bahwa semua orang memiliki emosi marah, tetapi bagaimana orang-orang ini dapat menyalurkan atau menggunakannya dengan benar dan tepat sehingga tidak merugikan diri sendiri atau orang lain. Kemarahan adalah emosi alami, diekspresikan secara tidak tepat, orang lain terluka dan pengalaman negatif diciptakan.

Penelitian yang dilakukan oleh Rachmawati dan Masykur yang berjudul "Pengalaman Ibu Yang Memiliki Anak Down Syndrome", Orang tua mengalami stres berat ketika memiliki anak berkebutuhan khusus dan hal tersebut dapat mempengaruhi kesehatan mental mereka. Pernyataan ini didukung oleh pendapat Lestari bahwa salah satu sumber stres adalah adanya anggota keluarga yang berkebutuhan khusus. Stres orang tua dapat memancing respons emosional dalam dirinya, yang disebabkan oleh penolakan dari keluarga dan orang-orang di sekitarnya. Ketika anak berkebutuhan khusus didiagnosis, peran utama dimainkan oleh orang tua, yang memiliki andil terbesar dalam merawat anak mereka yang memiliki kondisi medis berbeda dari anak normal.

Pada penelitian ini, peneliti ingin memperoleh gambaran yang lebih mendalam dalam manajemen emosi orang tua yang memiliki anak berkebutuhan khusus. Subjek penelitian adalah orang tua dengan anak berkebutuhan khusus di SD Immersion, SD Inklusi di Ponorogo.

SD Immersion adalah Sekolah Dasar yang didalamnya memiliki siswa normal seperti pada umumnya, namun didalamnya juga terdapat siswa dengan kebutuhan khusus. Setiap kelas maksimal hanya 17 siswa dengan anak berkebutuhan khusus 3 sampai 6 siswa per kelas. Untuk guru pun terdapat guru kelas dengan mata pelajaran yang diampu serta guru shadow atau pendamping khusus untuk mendampingi anak berkebutuhan khususnya. ${ }^{14}$

Indikator manajemen emosi menurut Goleman.

a. Mengakui emosi

Mengenali emosi Anda adalah kemampuan untuk mengenali perasaan ketika perasaan itu muncul. Kemampuan ini merupakan dasar dari kecerdasan emosional, yaitu persepsi tentang emosi diri sendiri. Pemahaman diri membuat kita lebih sadar hendak atmosfer

13 Paul Ekman, Emotions Revealed: Recognizing Faces and Feelings to Improve Communication and Emotional Life (English: Henry Holt and Co, 2003).

14 "Observasi di SD Immersion, 2021." 
hati serta benak tentang atmosfer hati; kala kita kurang waspada, orang gampang larut dalam arus emosi serta dikendalikan oleh emosi. Pemahaman diri tidak menjamin kemampuan emosi, namun ialah ketentuan berarti untuk mengatur emosi supaya orang bisa dengan gampang mengendalikannya.

b. Mengelola emosi

Berurusan dengan emosi adalah kemampuan seseorang untuk menghadapi perasaan sehingga dapat diekspresikan secara tepat untuk mencapai keseimbangan dalam diri orang tersebut. Menjaga emosi yang mengkhawatirkan tetap terkendali adalah kunci kesejahteraan emosional. Emosi berlebihan yang menumpuk terlalu lama menghancurkan stabilitas kita. Keterampilan ini mencakup kemampuan untuk menghibur diri sendiri, menghilangkan kecemasan, perubahan suasana hati atau iritasi dan konsekuensinya, dan kemampuan untuk mengatasi stres.

c. Mendapatkan motivasi

untuk mencapai kinerja harus dicapai melalui motivasi secara rinci, yang berarti bahwa memiliki ketekunan untuk menahan diri dari memuaskan dan mengendalikan dorongan hati, dan perasaan motivasi yang positif, yaitu semangat, gairah, optimisme dan kepercayaan diri.

d. Mengenali emosi orang lain

Keahlian dalam mengidentifikasi emosi orang lain pula diketahui selaku empati. Bagi Goleman, keahlian seorang untuk mengidentifikasi ataupun menjaga orang lain menampilkan keahlian seorang untuk berempati. Orang dengan kapasitas berempati lebih mampu menangkap isyarat sosial tersembunyi yang menunjukkan apa yang dibutuhkan orang lain untuk lebih menerima sudut pandang orang lain, lebih peka terhadap perasaan orang lain, dan lebih mendengarkan orang lain. istirahat.

e. Membangun Hubungan

Keterampilan membangun hubungan adalah keterampilan yang mendukung popularitas, kepemimpinan, dan kesuksesan, antara lain. Keterampilan komunikasi adalah keterampilan penting untuk membangun hubungan yang sukses. Terkadang sulit bagi orang untuk mendapatkan apa yang mereka inginkan dan juga sulit untuk memahami keinginan dan keinginan orang lain.

\section{B. METODE PENELITIAN}

Penelitian ini merupakan penelitian lapangan, yaitu penelitian yang langsung ke lapangan atau ke suatu tempat yang menjadi bagian dari penelitian, sehingga fokus penelitian ini adalah mencari dan mengkaji data di lapangan dengan permasalahan yang diajukan. 
Pendekatan dalam penelitian ini adalah pendekatan kualitatif. Penelitian kualitatif adalah penelitian yang didasarkan pada filosofi positivisme yang digunakan untuk mempelajari keadaan benda-benda alam, dengan peneliti sebagai alat utamanya. ${ }^{15}$

Penelitian ini dilaksanakan di SD Immersion Ponorogo. Alasan pemilihan lokasi karena SD Immersion merupakan SD Inklusi, dimana terdapat 26 anak berkebutuhan khusus dari kelas 1-6.

Data adalah fakta yang dikumpulkan oleh peneliti, yang bertujuan untuk menyelesaikan masalah ataupun untuk menjawab pertanyaan dari peneliti. ${ }^{16}$ Penelitian ini berfokus pada data pengelolaan emosi orang tua anak berkebutuhan khusus.

Sumber informasi merupakan sumber riset dimana informasi itu terletak. Sumber informasi bisa berbentuk objek, pergerakan, orang, tempat, dan sebagainya. Peneliti memakai sumber informasi primer. Sumber informasi primer dalam penelitian ini berbentuk informasi yang didapatkan langsung dari responden lewat hasil wawancara peneliti dengan pengasuh yakni orang tua dengan anak berkebutuhan khusus.

Teknik pengumpulan data adalah merupakan langkah terpenting dalam penelitian yang memiliki tujuan untuk memperoleh data. Oleh karena itu, metode pengumpulan data dalam penelitian ini adalah sebagai berikut: observasi (observasi) dan wawancara (interview).

Dalam penelitian yang dilakukan ini uji kredibilitas dilakukan dengan menggunakan triangulasi sumber. Triangulasi sumber digunakan menguji kredibilitas data dan kemudian dipergunakan dengan cara memverifikasi data yang didapatkan dari berbagai sumber.17

Teknik komputasi dalam penelitian ini adalah deskriptif kualitatif, meliputi.

1. Reduksi data, yaitu menjadikan satu, kemudian memfokuskan pada hal-hal yang pokok, mencari tema dan pola. Dengan cara ini, setelah reduksi, data dapat memberikan gambaran yang lebih jelas dan memudahkan peneliti untuk mengumpulkan lebih banyak data dan mencarinya jika diperlukan. ${ }^{18}$

2. Penyajian data adalah semua informasi yang dikumpulkan sehingga ditarik suatu kesimpulan dari semua informasi tersebut, yang kemudian diambil untuk penyajian data yang biasanya digunakan dengan teks naratif. ${ }^{19}$

3. Kesimpulan merupakan penemuan yang belum sempat terbuat tadinya. Penemuan bisa berbentuk deskripsi ataupun cerminan sesuatu objek yang tadinya tidak jelas sehabis dicoba riset, dapat berupa hubungan, hipotesis ataupun teori secara acak/ interaktif.

4. Analisis data adalah suatu kegiatan untuk mencari dan menyusun data, data wawancara, dan catatan lapangan secara sistematis sehingga Anda dan orang lain dapat dengan

15 Sugiyono, Metode Penelitian Bisnis Pendekatan Kuantitatif, Kualitatif, Kombinasi Dan R\&D (Bandung: Alfabeta, 2017).

${ }^{16}$ Sandu Siyoto, Dasar Metodologi Penelitian (Yogyakarta: Literasi Media Publishing, 2015).

17 Sugiyono, Metode Penelitian Bisnis Pendekatan Kuantitatif, Kualitatif, Kombinasi Dan R\&D.

18 Sugiyono.

${ }^{19}$ Sugiyono. 
mudah memahaminya. Peneliti menggunakan metode induktif untuk menganalisis data. Metode induktif adalah cara menjelaskan data dari eksposisi data dan kemudian menuju teori. ${ }^{20}$

\section{HASIL DAN PEMBAHASAN}

Penelitian ini berdasarkan keadaan yang terjadi di lapangan yaitu di SD Immersion Ponorogo. Peneliti mengambil tema tentang manajemen emosi pada orang tua dengan anak berkebutuhan khusus dalam mendidik dan mengasuh anak mereka, penelitian ini menggunakan indikator dari Goleman dan hasil interview dan observasi dari lapangan adalah :

\section{Self Awareness (kesadaran diri)}

Kesadaran diri adalah mengakui emosi anda adalah kemampuan untuk mengenali perasaan ketika mereka muncul. Dimana perasaan emosi adalah perasaan yang wajar. Wawancara dengan Ibu Maria dengan anak berkebutuhan khusus speech delay: "Ya saya ini kalo bilang tidak emosi ya bohong bu, karena anak saya sudah 10 tahun dan belum lancar bicara, dan akademiknya juga belum bisa, ya gimana ya, kadang kalau ketemu orang atau saat berkumpul dan menceritakan anak masing-masing itu saya nelongso, apalagi saat daring dengan PR yang ada itu bikin saya emosi bu".21

Pertanyaan yang sama ditanyakan pada ibu Lia dengan anak berkebutuhan khusus gangguan konsentrasi tentang selfawareness: "Ya bu, sangat emosi malah, anak saya ini tidak bisa diam, maunya main saja, apalagi sudah kelas 3, belum lancar baca tulis, setiap disuruh belajar susahnya jan bu, tiap saat maunya main saja, jadi ya emosi banget bu saya ini sebenarnya, Cuma ya harus menyabarkan diri sih, habis mau gimana lagi".22

Kemudian wawancara dengan ibu Laili dengan anak berkebutuhan khusus autis tentang self awareness: "Kalo emosi ya kadang muncul bu, saat kemudian dia mengamuk saat di tempat umum, namun adakalanya dia itu nurut sekali, ya kaya gitu bu, tapi ya kalo emosi itu ya pasti pernah, apalagi kalau saya lagi repot atau ada masalah, kadang ya emosi banget". ${ }^{23}$

Narasumber keempat adalah ibu Dewi dengan anak berkebutuhan khusus down syndrome tentang self awareness mengatakan: "Kalo emosi ya saya sekarang sudah jarang sekali bu, paling bukan emosi dengan anaknya tapi emosi memendam diri sendiri saja sih, karena penerimaan saya kepada anak saya ya sudah iklas sih bu, alhamdulillah disyukuri saja". ${ }^{24}$

\footnotetext{
20 Sugiyono.

21 Maria, "Wawancara” (2021).

22 Lia, "Wawancara" (2021).

23 Laili, "Wawancara" (2021).

24 Dewi, "Wawancara" (2021).
} 
Dari keempat narasumber tersebut dapat disimpulkan bahwa kesadaran diri untuk mengakui emosinya sendiri sudah dilakukan oleh para orang tua. Kesadaran diri ini sebenarnya tidak menjamin untuk kemudian bisa mengendalikan emosinya, namun menyadari bahwa dirinya sedang emosi adalah syarat untuk dapat mengendalikan diri dari ungkapan emosi tersebut.

\section{Managing Emotion (pengaturan emosi)}

Mengelola emosi adalah kemampuan seseorang untuk menghadapi perasaan sehingga dapat diekspresikan secara tepat untuk mencapai keseimbangan dalam diri orang tersebut. Emosi berlebihan yang menumpuk terlalu lama menghancurkan stabilitas kita. Wawancara dengan ibu Maria dengan pertanyaan tentang pengaturan emosi menjawab: "Ya saya kurang bisa kalau mengatur emosi, karena anak saya tiga dan untuk anak ABK saya ini adalah anak yang paling besar, sehingga kadang marah menjadi kurang bisa saya tahan bu, kadang karena kondisi saya merasa sangat capek dan melakukan semua sendiri, mengurus mereka sendiri, suami kerja, jadi saat kemudian mengurus rumah dan anak sendiri membuat saya emosi sendiri bu". ${ }^{25}$

Ibu Lia dengan pertanyaan tentang pengaturan emosi menjawab: "Kalau saya memang paling tidak bisa mengontrol emosi saya bu, saat kemudian anak membuat ulah dan saat saya ada aktifitas lain, maka itu sangat sulit untuk mengontrol emosi saya. Kadang saya sampai teriak-teriak saat kemudian anak saya ini susah diatur, tiba-tiba keluar rumah, susah dibilangin, bahkan kalau saya lagi benar-benar tidak bisa mengontrol emosi saya, kadang saya sampai mencubitnya, sedih banget sebenarnya bu, tapi saya susah sekali mengontrol emosi saya dan akhirnya cuma bisa menyesal saat itu sudah terjadi, tapi memang bu, sangat susah sekali mengatur emosi saya ini." 26

Pada saat wawancara berlangsung ibu Lia dihampiri oleh anaknya yang tiba-tiba merengek minta mainan seperti punya temannya, ${ }^{27}$ dengan suara pelan tanpa emosi ibu Lia mengatakan "iya mas, nanti pulang sekolah ya, dan terjadi empat kali permintaan yang ditolak, dan anaknya tiba-tiba mengamuk dengan merebut mainan temannya, dan tampak ibu Lia emosi dengan berteriak dan menjewer telinga anaknya, dari hal ini tampak kesulitan dari orang tua dalam mengatur emosinya.

Ibu Laili dengan pertanyaan tentang pengaturan emosi menjawab menjawab: "Pas saya di rumah dalam mengontrol emosi saya lebih susah bu, karena anak saya kalau memang telat minum obat, atau kemudian lupa makan roti dan makanan tepung-tepungan maka anak saya akan mengamuk dan sangat agresif, sehingga ini membuat saya susah mengontrol emosi, apalagi saat anak saya sampai merusak barang, otomatis saya langsung berteriak dan emosi memuncak, begitu juga kalau lagi diluar rumah kadang dia sampai menjatuhkan display barang dagangan atau ulah apa saja yang pernah saya sampai mengganti barang

\footnotetext{
25 Maria, "Wawancara."

26 Lia, "Wawancara."

27 "Observasi pada saat wawancara berlangsung, 2021."
} 
karena rusak. Betul-betul menguras emosi bu, tapi saya tetap pengen banget bisa mengontrol emosi saya ini bu." 28

Tanggapan ibu Dewi dengan pertanyaan tentang pengaturan emosi menjawab: "Mengontrol emosi adalah pada awalnya berat bagi saya bu, kalo sekarang saya sudah menerima bu, saya sudah biasa dan tidak berat lagi dalam mengontrol emosi berkaitan dengan anak ABK saya. Alhamdulillah saya sudah ikhlas bu, kasihan anak saya nanti kalau melihat saya emosi, apalagi berkaitan dengan dia." 29

Kemudian Ibu Laili menambahkan: "Pernah bu, saya lari-lari keliling hypermart karena dia naik sepeda yang dijual di toko itu, rasanya malu sekali bu, pandangan pengunjung lain itu bener-bener membuat saya down bu, pernah saya sampai menangis karena tidak bisa mengontrol emosi saya. ${ }^{30}$

Dari jawaban narasumber, terdapat tiga narasumber yang tidak bisa mengontrol emosi, dan hanya satu narasumber yang sudah bisa mengontrol emosinya, walaupun dulu menurut narasumber itu adalah hal yang sulit. kemampuan seseorang untuk menghadapi perasaan sehingga dapat diekspresikan secara tepat untuk mencapai keseimbangan dalam diri orang tersebut. Menjaga emosi yang mengkhawatirkan tetap terkendali adalah kunci kesejahteraan emosional. emosi berlebihan yang menumpuk terlalu lama dapat menghancurkan kestabilan hidup. Kemampuan ini mencakup kemampuan untuk menghibur diri sendiri, menghilangkan rasa takut, perubahan suasana hati dan kemampuan untuk keluar dari perasaan stres.

\section{Motivating oneself (motivasi untuk diri sendiri)}

Pencapaian kinerja bisa dicapai dengan memotivasi dirinya sendiri yaitu dengan menanamkan semangat, optimisme dan tentunya menumbuhkan rasa percaya diri. Ibu Maria menjawab pertanyaan tentang bagaimana cara memotivasi diri sendiri mangatakan: "Saya kadang menyenangkan dan menghibur diri sendiri dengan melihat kebawah bu, dimana banyak anak yang lebih parah daripada anak saya, saya kadang menghibur diri dengan pergi ke tempat terapi dan duduk disitu agak lama, biasanya dari tempat itu saya agak merasa lebih baik". ${ }^{31}$

Ibu Lia menjawab pertanyaan tentang bagaimana cara memotivasi diri sendiri mangatakan: "Alhamdulillah bu, anak saya walaupun belum lancar baca tulis dan gangguan konsentrasi tingkat tinggi, tapi anak saya masih bisa diajak komunikasi walaupun sulit. Jadi kalau dalam memotivasi diri sendiri atau lebih tepatnya menghibur diri ya saya biasanya menghindari hal-hal yang membuat saya emosi bu, saya ajak anak saya jalan-jalan ke mal dan mainan, ya yang membuat saya emosi adalah saat mengerjakan tugas dan saat mulai

\footnotetext{
${ }^{28}$ Laili, "Wawancara."

29 Dewi, "Wawancara."

${ }^{30}$ Laili, "Wawancara."

31 Maria, "Wawancara."
} 
membaca menulis, saya betul-betul kesusahan saat harus memanage emosi saya, apalagi tugas anak, kerjaan, rumah, banyak sekali yang harus saya urus bu". 32

Kemudian ibu Laili menjawab pertanyaan tentang bagaimana cara memotivasi diri sendiri mangatakan: "Saya biasanya kalau memotivasi atau menyenangkan diri ya makan bu, hehe.. biasanya kalau saya pusing dan mau marah-marah saya keluar jajan bakso atau seblak bu, tapi anak saya tidak saya ajak, biasanya setelah itu emosi mereda". ${ }^{33}$

Ibu Dewi menjawab pertanyaan tentang bagaimana cara memotivasi diri sendiri mangatakan: "Kalau saya biasanya pas merasa lagi berat ya ambil wudhu dan sholat bu, sudah itu membuat saya merasa lebih tenang dan bisa menerima kenyataan." 34

Dari keempat narasumber diatas dapat disimpulkan bahwa semua narasumber sudah mengenali diri sendiri, sehingga bisa memotivasi diri sendiri, menanamkan semangat, optimisme dan tentunya menumbuhkan rasa percaya diri sehingga bisa membahagiakan dirinya sendiri agar semua tetap dalam kendali.

\section{Emphaty (empati)}

Empati adalah kemampuan mengenali emosi orang lain. Orang dengan empati yang tinggi lebih mampu lebih peka terhadap perasaan orang lain dan lebih mendengarkan orang lain. Ibu Maria menjawab pertanyaan wawancara dalam hal empati: "Mengenali anak saya adalah hal yang susah bu, karena dia belum bisa mengungkapkan perasaannya dengan katakata, namun kalau dari perilakunya saya sudah paham, biasanya dia akan berteriak-teriak atau membanting barang yang didekatnya." 35

Ibu Lia menjawab pertanyaan wawancara dalam hal empati: “Anak saya emosi saat saya mulai memaksa untuk belajar, entahlah bu, setiap saya pegang buku dia biasanya lari dan apabila saya memaksa dia akan mengamuk, namun anak saya agak lunak saat kemudian saya memberikan reward, entah itu jajan atau sekedar jalan-jalan naik mobil keliling kota. Itupun biasanya anak saya tidak lama mau belajarnya, namun saya benar-benar berusaha paham bahwa anak saya mengalami gangguan konsentrasi tingkat tinggi." 36

Kemudian ibu Laili juga menjawab pertanyaan wawancara dalam hal empati : “Anak saya ini gampang sekali emosi bu, dan saya biasanya kalau pas capek agak ikut terpancing. Anak saya ini banyak pantangannya bu, salah makan sedikit susah sekali misal disuruh konsentrasi, bahkan pas mengamuk tidak mengenal tempat dan waktu. Kalau mengenali dan memahami pas dia emosi sih biasanya saya kasih hp bu, nanti setelah agak reda biasanya saya ajak ngomong pelan-pelan." 37

\footnotetext{
32 Lia, "Wawancara."

33 Laili, "Wawancara."

${ }^{34}$ Dewi, "Wawancara."

35 Maria, "Wawancara."

36 Lia, "Wawancara."

37 Laili, "Wawancara."
} 
Narasumber berikutnya ibu Dewi menjawab pertanyaan wawancara dalam hal empati: "Kalo anak saya jarang emosi kok bu, ya mungkin karena kondisinya. Jadi dia paling senang kalau saya bikinkan kentang goreng, biasanya pasti dia mencium saya, atau misalkan pas saya diam saja atau terlihat lagi sedih dia akan senyum-senyum dan mengelus pipi saya." 38

Dari keempat narasumber dapat ditarik kesimpulan bahwa para ibu ini paham bagaimana anak berkebutuhan khusus mereka, paham waktu dimana anak saat emosi dan saat menginginkan sesuatu, sehingga orang tua di SD Immersion ini mampu dan peka terhadap perasaan anaknya.

\section{Social skill (keterampilan emosi)}

Keterampilan emosi adalah membangun hubungan yang harmonis antar orang, dalam hal ini berhubungan dengan orang tua dan anak berkebutuhan khusus mereka. Terkadang sulit bagi orang untuk mendapatkan apa yang mereka inginkan dan juga sulit untuk memahami keinginan dan tentunya keinginan orang lain. Ibu Maria menjawab hasil wawancara dalam hal keterampilan emosi yaitu: "Jadi kalau saya ya bu, sangat memposisikan diri saya dimana, jadi kalau di tempat umum, atau sekolah maka saya akan mendukung anak saya agar tetap merasa seperti anak yang lainnya dan biar dia tidak minder dengan anak yang lainnya." 39

Kemudian ibu Lia menjawab hasil wawancara dalam hal keterampilan emosi yaitu: "Keterampilan emosi disini sangat penting bu, karena anak saya memang hiperaktif, sehingga banyak yang ulah yang dilakukan, sehingga sering kemudian saya harus memperingatkan, Cuma dalam keterampilan emosi saya disini ya mau tidak mau dn harus mau bu, karena kita sadar kita ada dimana dan menghargai dimana tempat kita berada. Sehingga dengan memahami emosi anak maka akan membuat kita lebih paham lagi saat harus terampil mengolah emosi kita." 40

Berikutnya ibu Laili menjawab hasil wawancara dalam hal keterampilan emosi yaitu: "Keterampilan emosi saya masih kurang sih bu, Cuma kalau saya sih biasanya sudah siapsiap apabila saya akan keluar dengan anak saya dari rumah dan berhubunga dengan lingkunagn luar saya selalu siap obat dan bagaimana menghadapi kalau tiba-tiba dia mengamuk." 41

Kemudian ibu Dewi menjawab hasil wawancara dalam hal keterampilan emosi yaitu: "Alhamdulillah bu, saya sudah menerima dan bersyukur, sehingga saya apapun kondisinya dan dimanapun memahami dengan kondisi anak saya dengan selalu sabar dan sabar." 42

\footnotetext{
38 Dewi, "Wawancara."

39 Maria, "Wawancara."

${ }^{40}$ Lia, "Wawancara."

41 Laili, "Wawancara."

42 Dewi, "Wawancara."
} 
Kesimpulan dari keterampilan emosi diatas adalah bahwa untuk keterampilan emosi sudah dapat ditangani oleh orang tua yang dalam hal ini adalah ibu, dimana mereka telah memahami bagaimana anak mereka, sehingga lebih mudah mengatasinya.

\section{Analisa Data}

\section{Kesadaran Diri (Self Awareness)}

Pengetahuan diri menurut Daniel Goleman adalah kemampuan seseorang untuk mengetahui kekuatan, kelemahan, dorongan, nilai dan pengaruhnya terhadap orang lain. Singh lebih lanjut menekankan bahwa kesadaran diri mampu menghubungkan seseorang dengan perasaan, pikiran, dan tindakan pribadi mereka, sedemikian rupa sehingga membantu orang tersebut untuk memiliki gagasan yang lebih jelas tentang apa yang ingin mereka capai dalam hidup dan, oleh karena itu , untuk tingkat kompetensi Anda. bekerja. Kesadaran diri adalah dasar untuk pertumbuhan perilaku kecerdasan emosional, dan kesadaran diri mengacu pada kemampuan untuk membaca emosi seseorang dan mengenali efeknya untuk memandu keputusan, termasuk pilihan karir. Oleh karena itu, penting bagi orang untuk memiliki penilaian diri yang akurat dengan mengetahui kekuatan dan batasan mereka sendiri.

Orang tua yang memiliki anak berkebutuhan khusus di SD Immersion sudah memiliki kesadaran diri (Self Awareness), dimana mereka menyadari bahwa memiliki anak berkebutuhan khusus adalah takdir dan tidak bisa dirubah lagi. Mereka menyadari bahwa memang dalam mengasuh dan mendidik anak berkebutuhan khusus membuat mereka emosi dan mereka berusaha untuk mengenal emosi mereka dan meredamnya. Kesadaran diri bahwa mereka sedang emosi adalah pewujudan dari self awareness. Kesadaran diri ini sebenarnya tidak menjamin untuk kemudian bisa mengendalikan emosinya, namun menyadari bahwa dirinya sedang emosi adalah syarat untuk dapat mengendalikan diri dari ungkapan emosi tersebut.

\section{Managing Emotion (pengaturan emosi)}

Orang tua dari anak berkebutuhan khusus harus memiliki kemampuan untuk mengelola emosi yang dirasakan dan memahami pengaruhnya terhadap interaksi. Kemampuan ini meliputi kemampuan orang tua untuk mengelola emosi yang mereka rasakan ketika terjadi konflik dengan diri mereka sendiri atau dengan orang lain, dan pengaruh dari konflik emosi, terlepas dari apakah orang tua lebih mementingkan emosi atau perasaan mereka.

Berdasarkan hasil wawancara dengan narasumber dari pihak orang tua didapatkan hasil dari tiga narasumber yang ternyata tidak bisa mengontrol emosi, dan hanya satu narasumber yang sudah bisa mengontrol emosinya, walaupun dulu menurut narasumber itu adalah hal yang sulit. kemampuan seseorang untuk menghadapi perasaan sehingga dapat diekspresikan secara tepat untuk mencapai keseimbangan dalam diri orang tersebut. Menjaga emosi yang mengkhawatirkan tetap terkendali adalah kunci kesejahteraan emosional. emosi berlebihan yang menumpuk terlalu lama dapat menghancurkan kestabilan 
hidup. Kemampuan ini mencakup kemampuan untuk menghibur diri sendiri, menghilangkan rasa takut, perubahan suasana hati dan kemampuan untuk keluar dari perasaan stress.

\section{Motivating oneself (motivasi untuk diri sendiri)}

Memotivasi diri sendiri untuk mencapai kinerja harus dicapai melalui motivasi secara rinci, yang berarti bahwa memiliki ketekunan untuk menahan diri dari memuaskan dan mengendalikan dorongan hati, dan perasaan motivasi yang positif, yaitu semangat, gairah, optimisme dan kepercayaan diri.

Dari keempat narasumber diatas dapat disimpulkan bahwa semua narasumber sudah mengenali diri sendiri, sehingga bisa memotivasi diri sendiri, menanamkan semangat, optimisme dan tentunya menumbuhkan rasa percaya diri sehingga bisa membahagiakan dirinya sendiri agar semua tetap dalam kendali.

\section{Emphaty (empati)}

Menurut Zoll dan Enz (2012) empati dapat diartikan sebagai kemampuan dan kecenderungan seseorang ("observer") untuk memahami apa yang orang lain ("target") pikirkan dan rasakan pada situasi tertentu. Empati merupakan salah satu bentuk emosi kesadaran diri, selain rasa malu, rasa cemburu, rasa bangga dan rasa bersalah. Menurut Darwin, emosi-emosi tersebut berawal dari perkembangan kesadaran diri dan melibatkan penguasaan peraturan dan standar. ${ }^{43}$ Dari keempat narasumber dapat ditarik kesimpulan bahwa para ibu ini paham bagaimana anak berkebutuhan khusus mereka, paham waktu dimana anak saat emosi dan saat menginginkan sesuatu, sehingga orang tua di SD Immersion ini mampu dan peka terhadap perasaan anaknya.

\section{Social skill (keterampilan emosi)}

Kemampuan mengenali emosi orang lain juga dikenal sebagai empati. Menurut Goleman, kemampuan seseorang untuk mengenali atau merawat orang lain menunjukkan kemampuan seseorang untuk berempati. Orang dengan kapasitas berempati lebih mampu menangkap isyarat sosial tersembunyi yang menunjukkan apa yang dibutuhkan orang lain untuk lebih menerima sudut pandang orang lain, lebih peka terhadap perasaan orang lain, dan lebih mendengarkan orang lain.

Kesimpulan dari keterampilan emosi di atas adalah bahwa untuk keterampilan emosi sudah dapat ditangani oleh orang tua yang dalam hal ini adalah ibu, dimana mereka telah memahami bagaimana anak mereka, sehingga lebih mudah mengatasinya.

\footnotetext{
${ }^{43}$ Siyoto, Dasar Metodologi Penelitian.
} 


\section{PENUTUP}

\section{Simpulan}

Kesimpulan dari penelitian yang telah dilakukan diatas adalah :

1. Kesadaran Diri (Self Awareness)

Dalam penelitian ini, orang tua anak berkebutuhan khusus menyadari bahwa memang dalam mengasuh dan mendidik anak berkebutuhan khusus membuat mereka emosi dan mereka berusaha untuk mengenal emosi mereka dan meredamnya.

2. Pengaturan emosi (managing emotion)

Hasil penelitian ini menunjukkan terdapat tiga narasumber yang tidak bisa mengontrol emosi, dan hanya satu narasumber yang sudah bisa mengontrol emosinya

3. Motivasi untuk diri sendiri (motivating oneself)

Dari penelitian ini, semua narasumber sudah mengenali diri sendiri, sehingga bisa memotivasi diri sendiri, menanamkan semangat, optimisme dan tentunya menumbuhkan rasa percaya diri sehingga bisa membahagiakan dirinya sendiri agar semua tetap dalam kendali.

4. Empati (emphaty)

Dari penelitian ini menunjukkan bahwa para ibu ini paham bagaimana anak berkebutuhan khusus mereka, paham waktu dimana anak saat emosi dan saat menginginkan sesuatu, sehingga orang tua di SD Immersion ini mampu dan peka terhadap perasaan anaknya.

5. Keterampilan emosi (social skill)

Hasil dari penelitian ini, keterampilan emosi sudah dapat ditangani oleh orang tua yang dalam hal ini adalah ibu, dimana mereka telah memahami bagaimana anak mereka, sehingga lebih mudah mengatasinya.

Dari hasil wawancara dan observasi yang telah dilakukan, bahwa implementasi manajemen emosi pada orang tua dengan anak berkebutuhan khusus belum sepenuhnya bisa dilakukan. Dalam hal pengaturan emosi, dari empat narasumber, ada satu narasumber yang belum bisa mengatur emosinya dalam menghadapi anak berkebutuhan khususnya.

\section{Saran}

Orang tua yang menyadari dan melihatnya sebagai takdir, sehingga dapat mengoptimalkan kemampuan anak-anaknya dan mampu menerima kekurangan dari anak berkebutuhan khusus. Sedangkan orang tua yang tidak dapat menerima situasi anaknya dapat membuat orang tua memiliki perasaan rendah diri, merasa hancur dan depresi atas situasi yang dialami anaknya. Kemudian untuk penelitian selanjutnya narasumber bisa orang tua lengkap dengan menyertakan pihak ayah juga sebagai narasumber.

\section{E. DAFTAR PUSTAKA}

Aydin Aydan \& Yamac Ali. “The Relations between the Acceptance and Childrearing Attitudes 
of Parents of Children with Mental Disabilitie." Eurasian Journal of Educational Research, No. 54 (2014).

Desiningrum, Dinie Ratri. Psikologi Anak Berkebutuhan Khusus. Yogyakarta: Psikosain, 2016.

Ekman, Paul. Emotions Revealed: Recognizing Faces and Feelings to Improve Communication and Emotional Life. English: Henry Holt and Co, 2003.

Empati, Jurnal, Sarah Nur Rachmawati, dan Achmad Mujab Masykur. "Pengalaman Ibu yang Memiliki Anak Down Syndrome.” Empati: Jurnal Karya Ilmiah S1 Undip 5, No. 4 (2016): 822-30.

Kisworowati. "Strategi Coping Ibu dalam Menjalani Peran sebagai Orang Tua Tunggal." Surakarta, 2010.

Koentjaraningrat. Kebudayaan, Mentalitas dan Pembangunan. Yogyakarta: Pustaka Pelajar, 1985.

Koentjoro, Andayani. Psikologi Keluarga: Peran Ayah Menuju Coparenting. Surabaya: Citra Medika, 2004.

Novita, Eryanti. "Perbedaan Penerimaan Diri Ibu yang Memiliki Anak Tunagrahita Ditinjau dari Tingkat Pendidikan Di SLB-E PTP Medan." Jurnal Diversita 3, No. 1 (2017): 55. https://doi.org/10.31289/diversita.v3i1.1180.

Rachmayanti, S., and A. Zulkaida. "Penerimaan Diri Orangtua terhadap Anak Autisme dan Peranannya dalam Terapi Autisme." Jurnal Ilmiah Psikologi Gunadarma 1, No. 1 (2007): 97258.

Siyoto, Sandu. Dasar Metodologi Penelitian. Yogyakarta: Literasi Media Publishing, 2015.

Sugiyono. Metode Penelitian Bisnis Pendekatan Kuantitatif, Kualitatif, Kombinasi Dan R\&D. Bandung: Alfabeta, 2017. 